\title{
LEACHING OF NUTRIENTS FROM MIXED FERTILIZER IN SOME FINNISH SOILS
}

\author{
Johan Korkman \\ University of Helsinki, Department of Agricultural Chemistry
}

Received February 6, 1970

It has been claimed that a great deal of the nutrients applied to soils as fertilizers is getting washed out.

The nitrate anion is known to move easily in the soil (Tyler, BroAdbent \& Kondo 1958), although the movement of nitrate is not quite congruent with that of soil water (Cunningham \& Cooke 1958). The movement of ammonium and potassium cations depends on the cation exchange and fixation, the soil moisture and the cultivated plants (Munson \& Nelson 1963). The local sorption depends on the fertilizer compounds and the method of application. Aluminium, iron and calcium in the soil will react with the fertilizer phosphate forming products not easily soluble.

In these laboratory trials an attempt is made to follow the distribution of fertilizer nutrients, ammonium and nitrate nitrogen, phosphate and potassium, in different soil profiles after irrigation.

\section{Materials and methods}

10 surface-soil samples were collected in the region of Helsinki. In preliminary soil analyses the following characteristics were determined: $\mathrm{pH}$ (measured in $0.01 \mathrm{M} \mathrm{CaCl} \mathrm{Cl}_{2}$ ), texture (hydrometer method), cation exchange capacity (treatment with neutral ammonium acetate), organic carbon (wet combustion), fixation of potassium (ScHAcнтSCHABEL \& Köster 1960) and sorption of phosphorus (KAILA 1963). The results are given in Table 1. 
Table 1. Soil type, contents of clay and organic carbon, $\mathrm{pH}$, cation exchange capacity, potassium fixation and phosphorus sorption of the samples.

\begin{tabular}{rlrrrrrr}
\hline Sample & Soil type & $\begin{array}{c}\text { Clay } \\
\%\end{array}$ & $\begin{array}{c}\text { Org. C } \\
\%\end{array}$ & $\mathrm{pH}_{\mathrm{CaCl}_{2}}$ & \multicolumn{2}{c}{$\mathrm{C} \mathrm{E} \mathrm{C}$} \\
$\mathrm{me} / 100 \mathrm{~g}$ & $\begin{array}{c}\mathrm{K} \text {-fixation } \\
\mathrm{mg} / 100 \mathrm{~g}\end{array}$ & $\begin{array}{c}\text { P-sorption } \\
\mathrm{k}\end{array}$ \\
\hline 1 & loam & 45 & 4.0 & 5.6 & 26.6 & 22 & 203 \\
2 & finesand & 15 & 5.2 & 4.6 & 21.5 & 6 & 359 \\
3 & silt clay & 44 & 3.6 & 5.4 & 29.3 & 17 & 281 \\
4 & loam & 37 & 5.8 & 5.1 & 29.5 & 12 & 242 \\
5 & sand & 7 & 2.6 & 5.2 & 12.9 & 3 & 450 \\
6 & sandy clay & 41 & 4.5 & 7.0 & 29.1 & 15 & 162 \\
7 & heavy clay & 69 & 12.4 & 5.2 & 54.4 & 15 & 482 \\
8 & Carex peat & - & 29.1 & 4.3 & 71.9 & 5 & 524 \\
9 & silt clay & 57 & 8.4 & 4.5 & 43.4 & 4 & 560 \\
10 & sandy clay & 58 & 5.2 & 6.0 & 34.7 & 13 & 76 \\
\hline
\end{tabular}

The fertilizer used was a mixed one based on ammonium phosphate, $15-20-14$, in which the dominating compounds were $\mathrm{NH}_{4} \mathrm{H}_{2} \mathrm{PO}_{4}, \mathrm{NH}_{4} \mathrm{Cl}$ and $\mathrm{KCl} .2 .3 \%$ was nitrate nitrogen. $91 \%$ of the total phosphorus was dissolved in repeated washings with $0.01 \mathrm{M}$ $\mathrm{CaCl}_{2}$-solution.

Figure 1. Soils columns used in the leaching experiment.

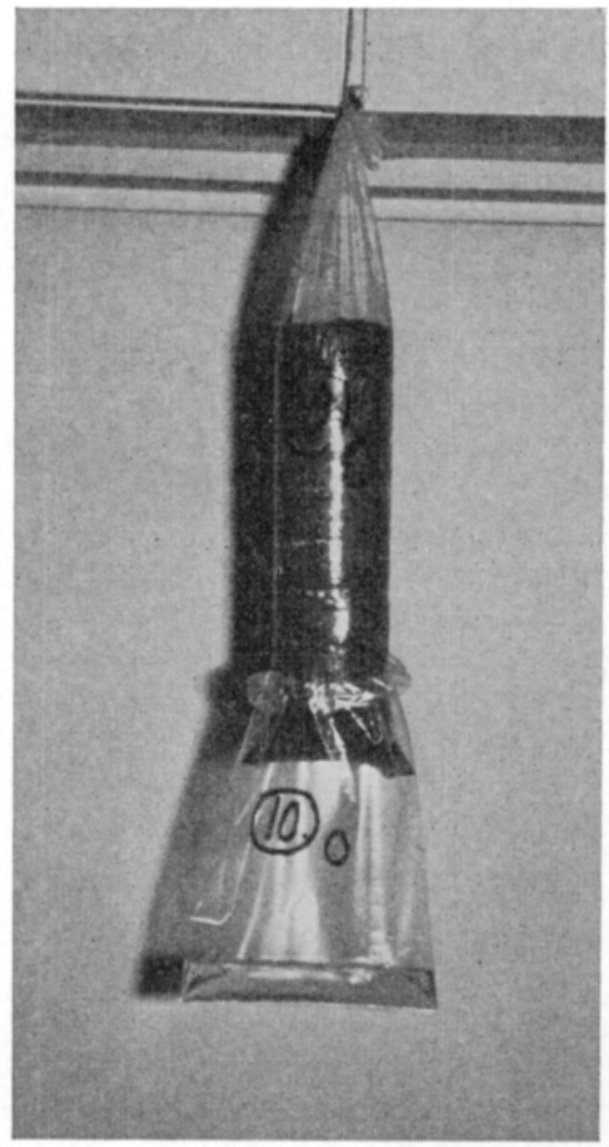


The inexpensive equipment used in the leaching experiment is shown in Figure 1. The plastic columns, $20 \mathrm{~cm}$ high with a diameter of about $5.5 \mathrm{~cm}$, were divided into 8 layers by circular filterpapers. Small plastic bags were attached to the columns to collect the percolating water. $2.5 \mathrm{~g}$ of the fertilizer was added on the surface. There were three columns of each soil, two of which were dressed, the third was a control. The columns were moistened to field capacity and allowed to remain so for a couple of days before the application of the fertilizer. Each column then received $75 \mathrm{ml}$ (appr. $30 \mathrm{~mm}$ ) of distilled water. Next day the irrigation was repeated. Two days later the plastic tubes were cut and the soil layers taken apart and allowed to dry. The percolated water was measured and diluted to volume. This solution was analysed for $\mathrm{NH}_{4}-\mathrm{N}$ (distillation), $\mathrm{NO}_{3}-\mathrm{N}$ (subsequent distillation with Devardas alloy), P (molybden blue method) and K (flame photometer). The amount of nutrients in the soil layers was analysed in the same way from an $0.01 \mathrm{~N} \mathrm{H}_{2} \mathrm{SO}_{4}$-extract (1:10, 1 hour).

\section{Results}

Figures 2 and 3 show the distribution of ammonium and nitrate nitrogen and of phosphorus and potassium in the soil columns at the end of the leaching experiment. The fertilizer nutrients washed out were calculated by subtracting the amount of percolated nutrients of the controls from that of the dressed columns.

No fertilizer phosphorus in any of the soil columns was leached out. In only five soils out of ten the percolated water contained potassium obviously originating from the fertilizer. In four soils no ammonium nitrogen came through and in a clay-soil rich in organic matter not even nitrate nitrogen was leached.

In these conditions the ammonium nitrogen moved slightly more rapidly than the potassium ion. The retarding effect of the clay fraction is apparent with both nutrients. With the exception of the sand and finesand soils (Nos. 2 and 5), these cations moved most easily in the Carex peat soil (No. 8), indicating the low capacity of organic matter to sorb these monovalent cations. The nitrate nitrogen moved through the columns like a drop: although nitrate moves slower than water, the nitrate front advances in the soil without leaving any permanent increase in the nitrate concentration in the passed soil layers.

When interpreting the results attention should be paid to the fact that $0.01 \mathrm{~N} \mathrm{H}_{2} \mathrm{SO}_{4}$ did not extract the fertilizer nutrients completely. The total yield of the analyses was calculated from the differences between the amounts of nutrients in the fertilized soils and the controls. The yields as a percentage of the application were as follows:

$\begin{array}{lccccc} & \mathrm{NH}_{4}-\mathrm{N} & \mathrm{NO}_{3}-\mathrm{N} & \mathrm{NH}_{4}-\mathrm{N}+\mathrm{NO}_{3}-\mathrm{N} & \mathrm{P} & \mathrm{K} \\ \text { mean } & 82 & 74 & 80 & 55 & 82 \\ \text { range } & 57-114 & 38-96 & 58-111 & 30-90 & 64-106\end{array}$

From the present material the theoretical maximum downward movements of the fertilizer nutrients were calculated using the linear regression analysis, while the results which did not significantly differ from the controls were not included. The point where the regression line and the control concentration line intersect, gives the maximum move- 
ment of the nutrients under these conditions (Table 2). For nitrate nitrogen the table gives the weighted mean of the concentration distribution.
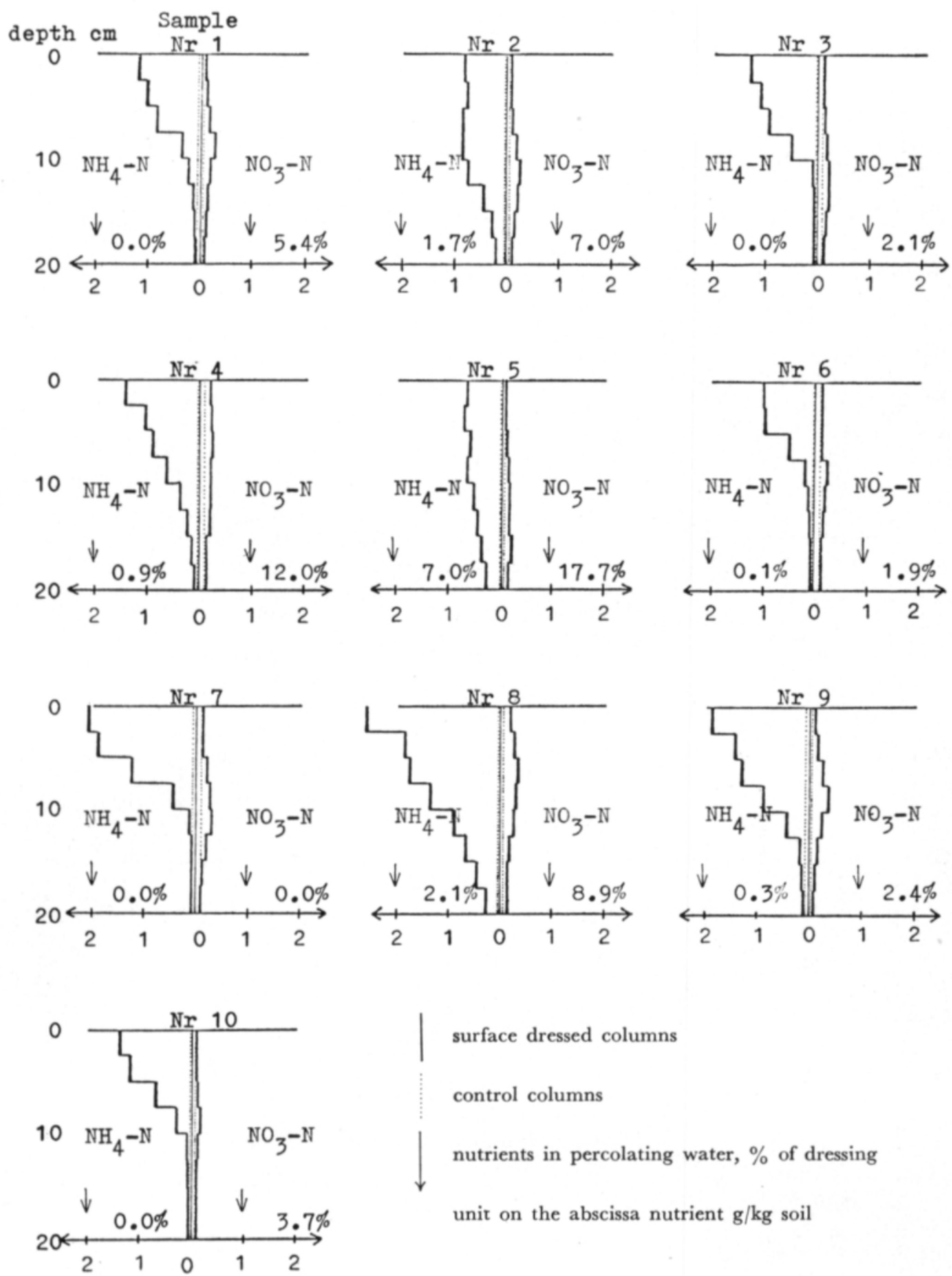

surface dressed columns

control columns

nutrients in percolating water, $\%$ of dressing

unit on the abscissa nutrient $\mathrm{g} / \mathrm{kg}$ soil

Figure 2. Distribution of ammonium and nitrate nitrogen in the surface dressed and control columns. 

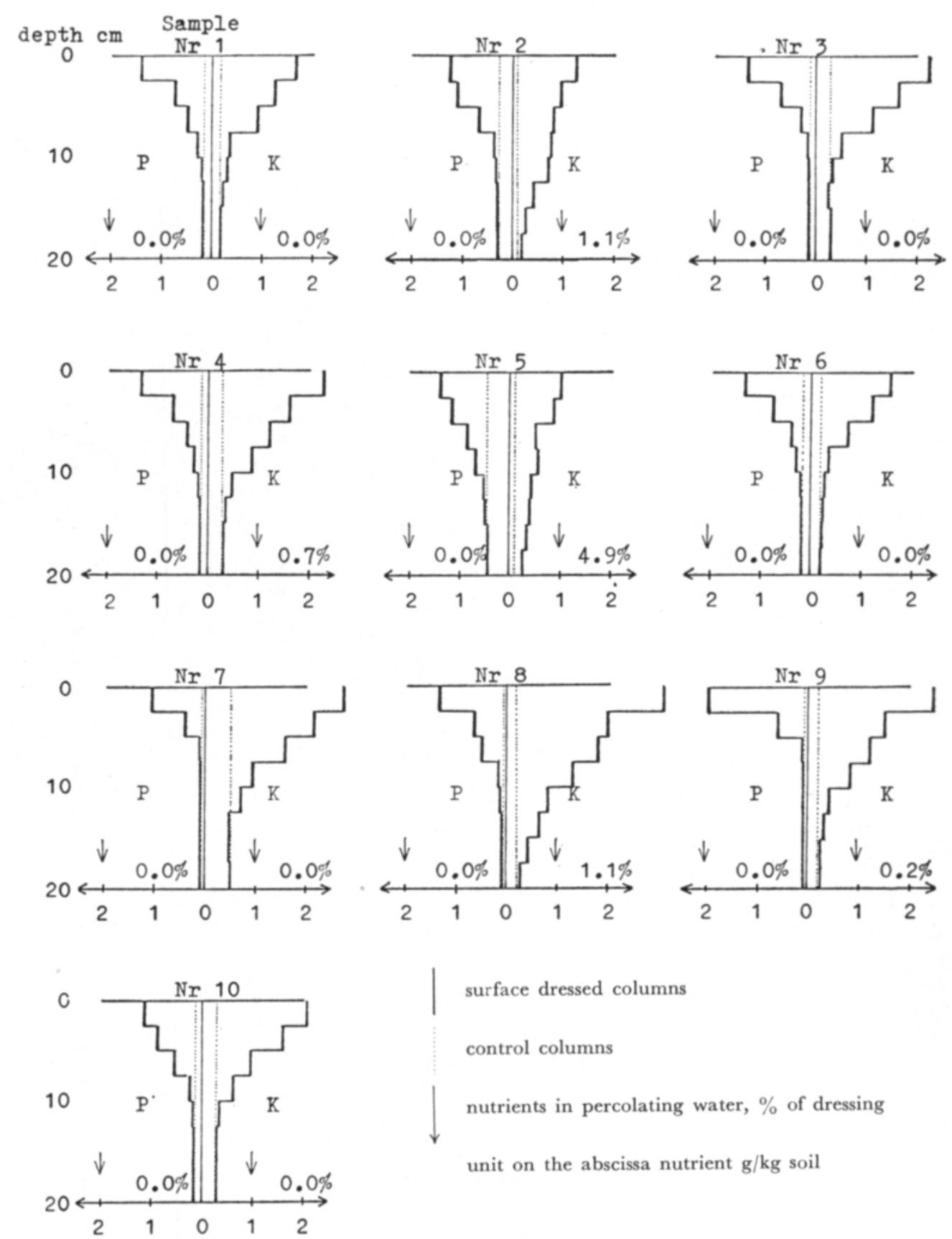

Figure 3. Distribution of phosphorus and potassium in the surface dressed and control columns. 
Table 2. Theoretical maximum downward movement of fertilizer ammonium nitrogen, phosphorus and potassium, and the weighted mean of nitrate concentration distribution.

\begin{tabular}{|c|c|c|c|c|}
\hline \multirow[b]{2}{*}{ Sample } & \multicolumn{3}{|c|}{ Maximum downward movement } & \multirow{2}{*}{$\begin{array}{c}\begin{array}{c}\text { Weighted mean of } \\
\text { concentration distribution }\end{array} \\
\frac{\mathrm{NO}_{3}-\mathrm{N}}{\mathrm{cm}}\end{array}$} \\
\hline & $\begin{array}{c}\mathrm{NH}_{4}-\mathrm{N} \\
\mathrm{cm}\end{array}$ & $\begin{array}{l}\mathrm{P} \\
\mathrm{cm}\end{array}$ & $\begin{array}{l}\mathrm{K} \\
\mathrm{cm}\end{array}$ & \\
\hline 1 & 16 & 12 & 11 & 10 \\
\hline 2 & 21 & 11 & 19 & 13 \\
\hline 3 & 12 & 8 & 11 & 12 \\
\hline 4 & 17 & 12 & 15 & 9 \\
\hline 5 & 24 & 13 & 19 & 13 \\
\hline 6 & 13 & 11 & 12 & 11 \\
\hline 7 & 15 & 6 & 11 & 10 \\
\hline 8 & 19 & 11 & 17 & 8 \\
\hline 9 & 16 & 7 & 15 & 9 \\
\hline 10 & 15 & 11 & 12 & 10 \\
\hline Mean & 16.7 & 10.1 & 14.3 & 10.5 \\
\hline
\end{tabular}

The dependence of the distribution of the nutrients on some soil properties was tested by total linear correlation. The correlation coefficients are listed in Table 3.

Table 3. Correlation coefficients for relationships between distance of nutrient movement and various soil characteristics

\begin{tabular}{lcccc}
\hline & $\mathrm{NH}_{4}-\mathrm{N}$ & $\mathrm{NO}_{3}-\mathrm{N}$ & $\mathrm{P}$ & $\mathrm{K}$ \\
\hline Clay & $-0.74^{*}$ & -0.26 & -0.42 & $-0.80^{* *}$ \\
Org. C & 0.11 & -0.63 & -0.13 & 0.20 \\
pH & -0.44 & 0.28 & -0.00 & -0.52 \\
C E C & -0.24 & - & - & -0.14 \\
K-fixation & - & - & - & $-0.85^{* *}$ \\
P-sorption & - & - & -0.01 & - \\
Clay + Org. C & $-0.76^{* *}$ & $-0.80^{* *}$ & -0.50 & $-0.87^{* *}$ \\
\hline
\end{tabular}

\section{Discussion}

None of the soil properties analysed were significantly correlated with the phosphorus distribution in the columns. In accordance with some results by KAILA (1964), an increase in the clay content seemed to intensify somewhat the phosphorus fixation also in this material. The coefficient of determination was, however, almost non-existent, obviously because of the heterogenous soil samples. The phosphorus sorption capacity determined according to the method of TERÄSVUORI (1954) was not, under these conditions, correlated with the distribution of phosphorus in this material.

The significant influence of the clay content on the fixation of potassium has been often stated (Volk 1934, Stanford 1948, Kaila 1965). In this experiment a fairly strong negative correlation was also observed between the clay content and the maximum movement of the fertilizer potassium. The weak correlation between the potassium distribution 
and the organic carbon and potassium distribution and the cation exchange capacity indicates that the selectivity of the fixing and exchanging mechanisms apparently eliminates the effect of certain factors. In mineral soils of the same kind, for instance, the cation exchange capacity would apparently be a useful basis for forecasting the distribution of the monovalent cations in the soil - in the present material the CEC was a useless variable for this purpose.

The behaviour of the ammonium ion resembles that of the potassium ion (PAGE \& Baver 1940, Stanford 1948, Barshad 1951, Kaila 1962). This was observed also in this analysis. The ammonium ion seemed to move slightly more easily than the potassium ion. The maximum length of the movement of the fertilizer ammonium nitrogen was thus well correlated with the clay content. The clay fraction retards the leaching, adsorbing cations in readily and difficultly exchangeable forms. This trial did not attempt to solve which of the forms dominates in the different soils (cf. KRANZ et al. 1944), but the question may be investigated with leaching experiments.

It has been suggested that the movement of nitrate nitrogen is connected with the soil structure (Gunningham \& Cooke 1958). The soil samples in question were ground to pass a $2 \mathrm{~mm}$ sieve. Hence no real crumb structure appeared. Nevertheless, the organic carbon and clay content, factors known to affect the structure, were closely correlated with the distribution of the nitrate in the soil columns.

According to these results, the leaching of fertilizer phosphorus through the soil seems very unlikely also under field conditions. In clay soils the leaching of ammonium nitrogen and potassium is obviously quite insignificant.

\section{$S u m$ m ary}

The movement of fertilizer nutrients in soil was followed in ten soils under laboratory conditions. The $20 \mathrm{~cm}$ high soil columns in plastic tubes were top-dressed with a mixed fertilizer, 15-20-14, and irrigated twice with $30 \mathrm{~mm}$ of water each time. The distribution of the nutrients was determined from the leachate and the extracts of dilute sulphuric acid.

Under these conditions, the average distance the nutrients moved downward was $17 \mathrm{~cm}$ for $\mathrm{NH}_{4}-\mathrm{N}, 10 \mathrm{~cm}$ for $\mathrm{P}$ and $14 \mathrm{~cm}$ for $\mathrm{K}$. The weighted mean of the nitrate concentration distribution was located $11 \mathrm{~cm}$ beneath the surface.

The distribution of the ammonium nitrogen and the potassium was correlated to the clay content of the soil $\left(\mathrm{r}=-0.74^{*}, \mathrm{r}=-0.80^{* *}\right)$. The percolation rate of the nitrate was correlated to the combined influence of organic carbon and clay, though the structure of the soil samples was destroyed before the experiment.

\section{REFERENCES}

Barshad, I. 1951. Cation exchange in soils: I. Soil Sci. 72: 361-371.

Cunningham, R. K. \& Cooke, G. W. 1958. Soil nitrogen II. Changes in levels of inorganic nitrogen in a clayloam soil caused by fertilizer additions by leaching and uptake by grass. J. Sci. Food Agric. 9: $317-324$.

KArla, A. 1962. Fixation of ammonium in Finnish soils. J. Sci. Agr. Soc. Finl. 34: 107-114.

-n- 1963. Dependence of the phosphate sorption capacity on the aluminium and iron in Finnish soils. Ibid. 35: 165-177. 
— - 1964. Forms of newly retained phosphorus in mineral soils. Ibid. 36: 65-76.

$\longrightarrow-1965$. Fixation of potassium in Finnish soils. Ibid. 37: 116-126.

Krantz, B. A., Ohlrogge, A. J. \& Scarseth, G. D. 1944. Movement of nitrogen in soils. Soil Sci. Soc. Amer. Proc. 8: 189-195.

Munson, R. D. \& Nelson, W. L. 1963. Movement of applied potassium in soils. J. Agric. Food Chem. 11: $193-201$.

Page, J. B. \& Baver, L. D. 1940. Ionic size in relation to fixation of cations by colloidal clay. Soil Sci. Soc. Amer. Proc. 4: 150-155.

SснаснтsснавеL, P. \& Köster, W. 1960. Chemische Untersuchungen an Marschen. II. Z. Pflanzenernähr., Düng., Bodenkunde 89: 148-159.

StANFord, G. 1948. Fixation of potassium in soils under moist conditions and on drying in relation to type of clay mineral. Soil Sci. Soc. Amer. Proc. 12: 167-171.

TerÄsvuorI, A. 1954. Ủber die Anwendung saurer Extraktionslösungen zur Bestimmung des Phosphordüngerbedarfs des Bodens, nebst theoretischen Erörterungen über den Phosphorzustand des Bodens. Publ. Staatl. Landw. Versuchsw. Finland N:r 141.

Tyler, K. B., Broadbent, F. E. \& Kondo, V. 1958. Nitrogen movement in simulated cross section of field soils. Agron. J. 50: 626-628.

Volk, N. J. 1934. The fixation of potash in difficultly available form in soils. Soil Sci. 37: $267-287$.

\section{SELOSTUS:}

\section{SEOSLANNOITTEEN RAVINTEIDEN HUUHTOUTUMINEN}

JoHan KORKMAN

Helsingin yliopiston maanviljelyskemian laitos

Ravinteiden liikkumista seurattiin laboratoriossa kymmenessä maassa. $20 \mathrm{~cm}$ korkeat maapylväät lannoitettiin pinnastaan normaali super Y-lannoksella ja kasteltiin kahdesti 30 mm:llä vettä. Ravinteiden jakautuminen eri maissa todettiin laimeasta rikkihappouutteesta.

Näissä oloissa lannoitteen vaikutus ulottui keskimäärin $\mathrm{NH}_{4}-\mathrm{N}$ :n osalta $17 \mathrm{~cm}$ päähän sijoitustasosta, fosforin osalta $10 \mathrm{~cm}$ päähän ja kaliumin osalta $14 \mathrm{~cm}$ päähän. Nitraattijakautuman painopiste sijaitsi $11 \mathrm{~cm}$ etäisyydellä sijoitustasosta.

Ammoniumtypen ja kaliumin liikkuminen maassa korreloitui verraten hyvin maan saveksen pitoisuuden kanssa $\left(\mathrm{r}=-0.74 *, \mathrm{r}=-0.80^{* *}\right)$. Nitraattitypen jakautuminen oli melko tiiviisti kytkeytynyt orgaanisen hiilen ja saveksen yhteisvaikutukseen, vaikkakin maanäytteiden rakenne oli tuhottu homogenisointivaiheessa. 